\title{
Simulated Peak Flows and Water-Surface Profiles for Scott Creek near Sylva, North Carolina
}

By BENJAMIN F. POPE

U.S. GEOLOGICAL SURVEY

Water-Resources Investigations Report 96-4226

Prepared in cooperation with Jackson County, North Carolina

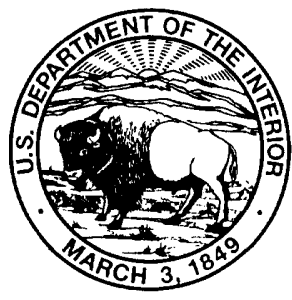




\title{
U.S. DEPARTMENT OF THE INTERIOR BRUCE BABBITT, Secretary
}

\author{
U.S. GEOLOGICAL SURVEY \\ Gordon P. Eaton, Director
}

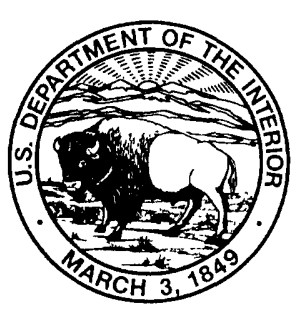

The use of firm, trade, and brand names in this report is for identification purposes

only and does not constitute endorsement by the U.S. Geological Survey.

For additional information write to:

District Chief

U.S. Geological Survey

3916 Sunset Ridge Road

Raleigh, NC 27607
Copies of this report can be purchased from:

U.S. Geological Survey

Information Services

Box 25286

Federal Center

Denver, CO 80225 


\section{CONTENTS}

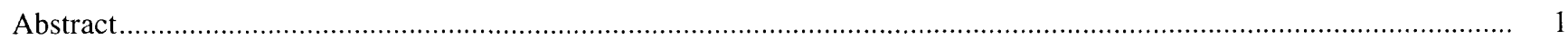

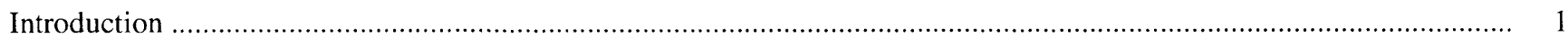

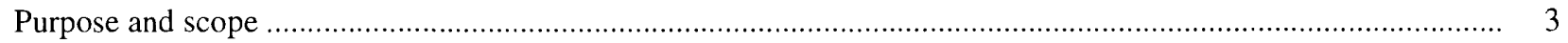

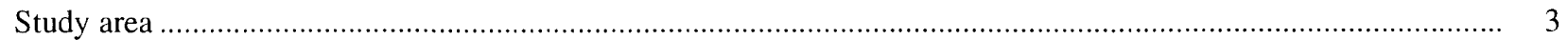

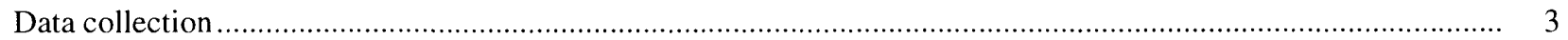

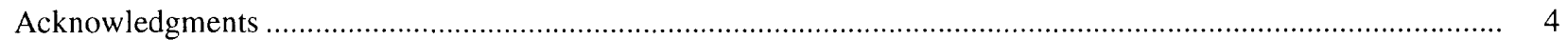

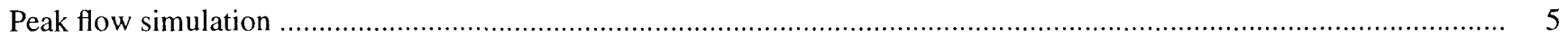

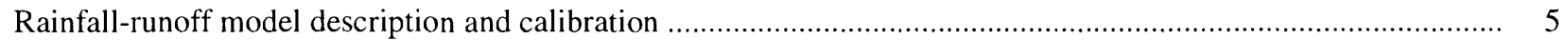

Antecedent conditions and synthetic rainfall data ............................................................................ 8

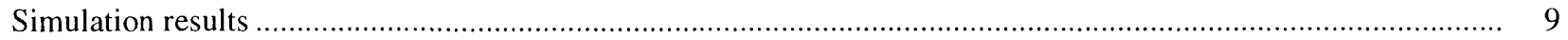

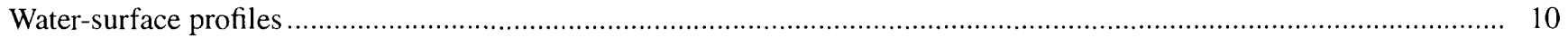

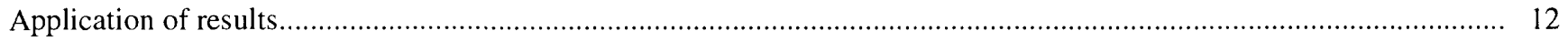

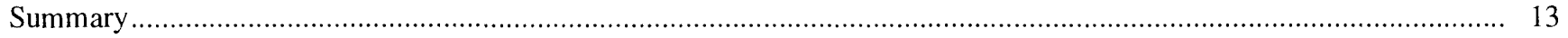

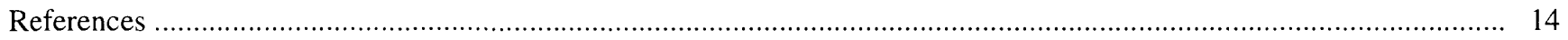

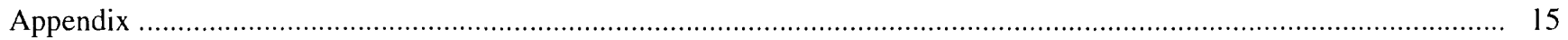

\section{ILLUSTRATIONS}

1. Map of Jackson County showing Scott Creek Basin divide and locations of streamflow gages, rainfall gages, and climatic measuring stations

2-8. Graphs showing:

2. Computed flood-frequency distribution for Scott Creek above Sylva, N.C.

3. Simulated and observed runoff volumes and peak flows for Scott Creek above Sylva, N.C...........................

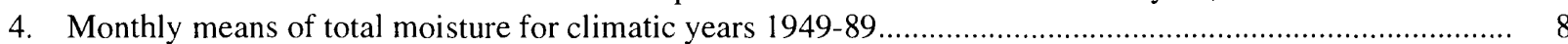

5. Simulated and observed peak flows for Scott Creek above Sylva, N.C., in response to selected 24 -hour rainfall events.....

6. Dimensionless input rainfall intensity and average dimensionless simulated flood hydrograph for Scott Creek above Sylva, N.C.

7. Water-surface profiles for selected observed and simulated peak flows along the reach of Scott Creek flowing through Sylva, N.C.

8. Stage-discharge relations (rating curves) in effect in 1975 and 1995 for Scott Creek above Sylva, N.C.

\section{TABLES}

1. Data-collection sites in Scott Creek Basin and surrounding areas.....

2. Total storm rainfall, observed and simulated runoff volumes, and observed and simulated peak flows for events used in calibration of the RRM

3. Period and total rainfall for antecedent moisture conditions data used in peak-flow simulations

4. Simulated peak flows for selected 24-hour rainfall amounts and antecedent moisture conditions.

A-1. Units, definition, and calibrated value for the RRM parameters used in peak flow simulation at Scott Creek above Sylva, N.C. 


\begin{tabular}{|c|c|c|}
\hline Multiply & By & To obtain \\
\hline \multicolumn{3}{|c|}{ Length } \\
\hline foot (ft) & 0.3048 & meter \\
\hline mile (mi) & 1.609 & kilometer \\
\hline & 0.4047 & hectare \\
\hline square mile $\left(\mathrm{mi}^{2}\right)$ & 2.590 & square kilometer \\
\hline \multicolumn{3}{|c|}{ Flow } \\
\hline cubic foot per second $\left(\mathrm{ft}^{3} / \mathrm{s}\right)$ & 0.02832 & cubic meter per second \\
\hline
\end{tabular}

Sea level: In this report "sea level" refers to the National Geodetic Vertical Datum of 1929 (NGVD) - a geodetic datum derived from a general adjustment of the first-order level nets of both the United States and Canada, formerly called Sea Level Datum of 1929.

\section{Definitions:}

FEMA Federal Emergency Management Agency

HEC Hydraulic Engineering Center

NWIS National Water Information System

NWS National Weather Service

RRM Rainfall-runoff model

TVA Tennessee Valley Authority

USFS U.S. Forest Service

USGS U.S. Geological Survey 


\title{
Simulated Peak Flows and Water-Surface Profiles for Scott Creek near Sylva, North Carolina
}

\author{
By Benjamin F. Pope
}

\section{ABSTRACT}

Peak flows were simulated for Scott Creek, just upstream from Sylva, in Jackson County, North Carolina, in order to provide Jackson County officials with information that can be used to improve preparation for and response to flash floods along the reach of Scott Creek that flows through Sylva. A U.S. Geological Survey rainfallrunoff model was calibrated using observed rainfall and streamflow data collected from March 1994 through September 1995. Standard errors for calibration were 34 percent for runoff volumes and 21 percent for peak flows. The calibrated model was used to simulate peak flows resulting from synthetic rainfall amounts of 1.0, 2.5, 5.0, and 7.5 inches in 24-hour periods. For each rainfall amount, peak flows were simulated under low-, moderate-, and high-antecedent soil-moisture conditions, represented by selected 3-month periods of daily rainfall and evaporation record from nearby climatic-data measuring stations. Simulated peak flows ranged from 89 to 10,100 cubic feet per second.

Profiles of water-surface elevations for selected observed and simulated peak flows were computed for the reach of Scott Creek that flows through Sylva, North Carolina. The profiles were computed using the U.S. Army Corps of Engineers HEC-2 Water Surface Profiles computer program and channel cross-section data collected by the Tennessee Valley Authority. The stage-discharge relation for Scott Creek at the simulation site has changed since the collection of the cross-section data. These changes, however, are such that the water-surface profiles presented in this report likely overestimate the true water-surface elevations at the simulation site for a given peak flow.

\section{INTRODUCTION}

Scott Creek drains about 59 square miles $\left(\mathrm{mi}^{2}\right)$ of northeast Jackson County, in the mountains of southwestern North Carolina. The creek flows westward across the county from its headwaters near Balsam Gap, through Sylva and Dillsboro, and into the Tuckasegee River (fig. 1). Large topographic relief in the drainage basin and steep stream slopes in the tributaries and main channel give rise to the potential for flash flooding. Flash flooding in the reach of Scott Creek that passes through Sylva is of special concern because of the proximity of businesses and residences to the stream.

Jackson County officials recognize the need to improve preparation for and response to flash floods along this reach of Scott Creek. In addition to the local needs, there also is need for better understanding of the relation between rainfall amounts and resulting peak flows in mountainous basins similar to the Scott Creek Basin. In response to these needs, the U.S. Geological Survey (USGS) in cooperation with Jackson County initiated an investigation in 1993 of the effects of various amounts of rainfall in the drainage basin on flows in Scott Creek in the Sylva area. The investigation included the application of a rainfallrunoff model to simulate peak flows in the creek and application of a step-backwater model to estimate flood elevations for the simulated peak flows. Results of the investigation can be used to qualitatively estimate peak flows and water-surface profiles that result from actual conditions. 


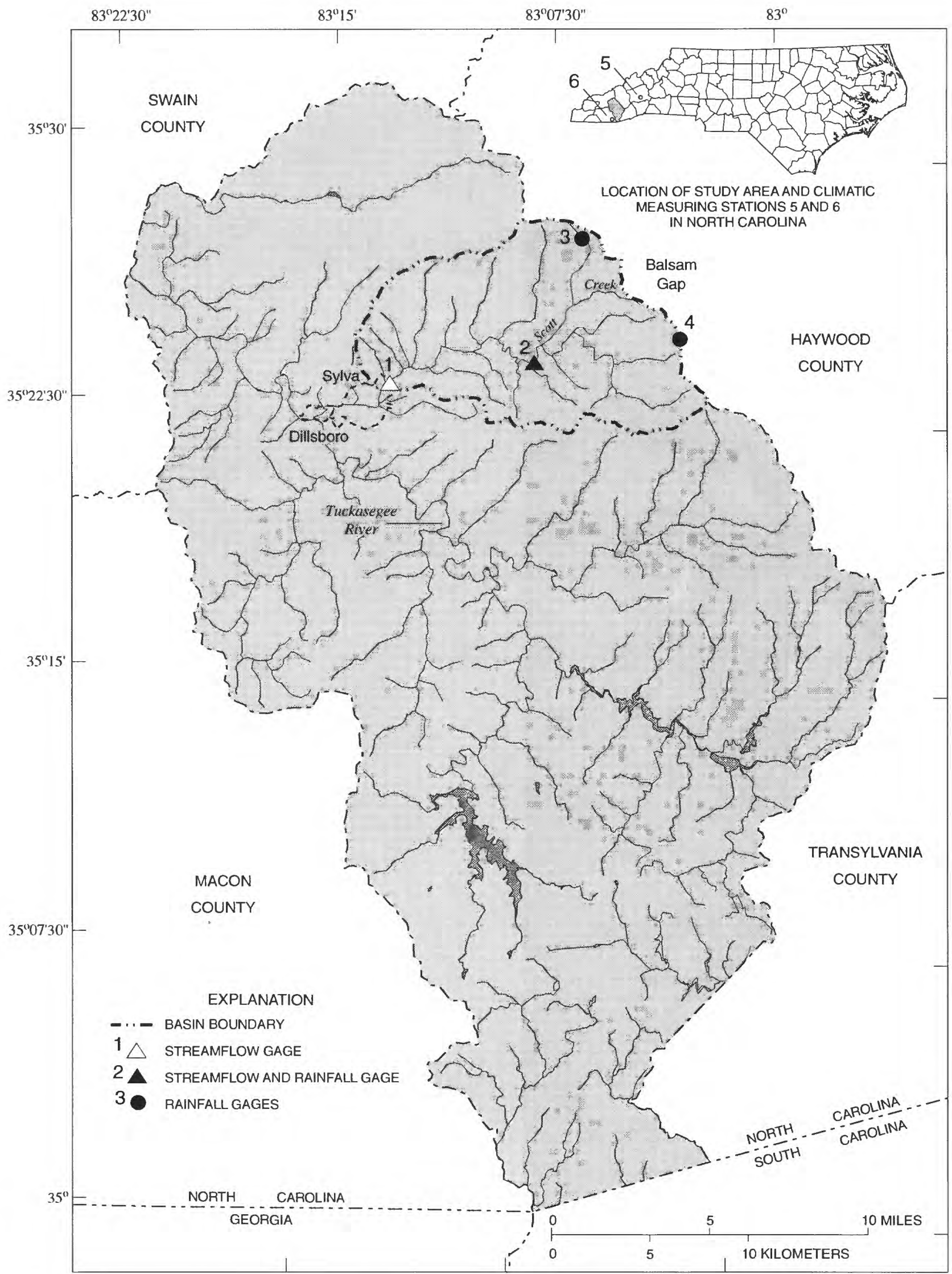

Figure 1. Jackson County, showing Scott Creek Basin divide and locations of streamflow gages, rainfall gages, and climatic measuring stations. 


\section{Purpose and Scope}

This report presents simulated peak flows for Scott Creek at site 1 (fig. 1; table 1) in response to synthetic rainfall events in the basin and estimated flood elevations associated with selected peak flows for the stream reach flowing through Sylva. Peak flows representing the response of the basin to 24-hour rainfall amounts ranging from 1.0 to 7.5 inches (in.) under three different antecedent soil-moisture conditions were simulated using the USGS rainfallrunoff model (RRM) (Dawdy and others, 1972). The RRM was calibrated by using data from one USGS stream gage and three USGS rainfall gages in the Scott Creek Basin, along with evaporation data obtained from nearby National Weather Service (NWS) and U.S. Forest Service (USFS) climatic stations.

The U.S. Army Corps of Engineers Hydraulic Engineering Center (HEC) Water Surface Profiles computer program (HEC-2) (U.S. Army Corps of Engineers Hydrologic Engineering Center, 1991) was used to compute profiles of water-surface elevations along the reach of Scott Creek that flows through Sylva. Channel cross sections and hydraulic properties required for the application of HEC-2 to the reach of Scott Creek that flows through Sylva were obtained from the Tennessee Valley Authority (TVA) (R.A. Milstead, Tennessee Valley Authority, written commun., June 28, 1996).

\section{Study Area}

The Scott Creek Basin is contained entirely within Jackson County (fig. 1). Scott Creek rises near Balsam Gap at the eastern boundary of Jackson County, at an elevation of about 3,400 feet ( $\mathrm{ft}$ ), and flows westward, falling to an elevation of about 2,060 ft at the streamflow gage upstream from Sylva and then to about $2,000 \mathrm{ft}$ where the stream flows into the Tuckasegee River. Scott Creek is flanked on the north by mountain peaks rising to more than $6,200 \mathrm{ft}$ and on the south by peaks rising to more than $5,000 \mathrm{ft}$.

Upstream from Sylva, the basin, which is sparsely populated and lightly developed, is primarily forested with some small areas of cultivated fields and pasture. The areas downstream from the Sylva gage are relatively more developed; however, development is generally limited to streamside areas in this part of the basin.

\section{Data Collection}

Two streamflow gages (fig. 1; table 1) and three rainfall gages (fig. 1; table 1) were installed in the basin by the USGS for this investigation. The streamflow gages were operated from January 1993 through September 1995; discharge records for these two gages were published in U.S. Geological Survey annual water-data reports (Barker and others, 1994; Ragland

Table 1. Data-collection sites in Scott Creek Basin and surrounding areas [mi ${ }^{2}$, square mile; -, not applicable]

\begin{tabular}{|c|c|c|c|c|}
\hline $\begin{array}{c}\text { Site } \\
\text { number } \\
\text { (fig. 1) }\end{array}$ & $\begin{array}{l}\text { USGS station } \\
\text { number }\end{array}$ & Station name & Data collected & $\begin{array}{c}\text { Drainage } \\
\text { area } \\
\left(\mathrm{mi}^{2}\right)\end{array}$ \\
\hline 1 & 03509000 & Scott Creek above Sylva, N.C. & discharge & 51.0 \\
\hline 2 & 03508910 & Scott Creek at Willits-Ochre Hill, N.C. & discharge $^{1}$, rainfall & 22.4 \\
\hline 3 & 352708083061445 & Woodfin Cascades Overlook & rainfall & - \\
\hline 4 & 352435083024245 & Grassy Ridge Mine Overlook & rainfall & - \\
\hline 5 & - & $\begin{array}{l}\text { National Weather Service, Asheville } \\
\text { Weather Station }\end{array}$ & rainfall & - \\
\hline 6 & - & $\begin{array}{l}\text { U.S. Forest Service, Coweeta Experimental } \\
\text { Station }\end{array}$ & evaporation & - \\
\hline
\end{tabular}

${ }^{1}$ Data not used in model calibration. 
and others, 1995, 1996). The rainfall gages were operated from March 1994 through September 1995; rainfall records for these three gages were stored in the USGS National Water Information System (NWIS) data base. Streamflow data collected at site 1 and rainfall data collected at sites 2,3 , and 4 were used to calibrate the RRM. Daily evaporation and precipitation records from climatic sites located outside of the basin and operated by the NWS and USFS (fig. 1; table 1) also were used in the calibration and application of the RRM.

Prior to this study, 34 years of streamflow record were collected at site 1 during water years ${ }^{1} 1942-75$ (fig. 1; table 1). The highest peak flow of the total 37 years of record occurred during this investigation. On March 27, 1994, flow at site 1 peaked at 4,440 cubic feet per second $\left(\mathrm{ft}^{3} / \mathrm{s}\right)$ in response to a 24 -hour rainfall of 5.13 in. measured at site 2 . A second smaller but

\footnotetext{
${ }^{1}$ Water year is the period from October 1 to September 30 and is identified by the year in which it ends.
}

significant event occurred February 16, 1995, when flow at site 1 peaked at $1,450 \mathrm{ft}^{3} / \mathrm{s}$ in response to a 24-hour rainfall of $3.34 \mathrm{in}$. measured at site 2 . These peaks occurred in late winter, typically the wettest part of the year. Antecedent 3-month total rainfall amounts were $14.05 \mathrm{in}$. for the March 1994 event and $13.21 \mathrm{in}$. for the February 1995 event. These two peak flows have recurrence intervals of greater than 200 years (March 1994) and less than 2 years (February 1995), respectively, as determined by an estimate of the floodfrequency distribution based on the 37 years of record collected from 1942 to 1975 and 1993 to 1995 (fig. 2) (U.S. Water Resources Council, 1981).

\section{Acknowledgments}

This investigation was conducted in cooperation with Jackson County, North Carolina. The support of Mr. Donald Clawson, Jackson County Emergency Services Department; Mr. Bobby McMahon, Jackson County Land Records Office; and Mr. Tom Massie,

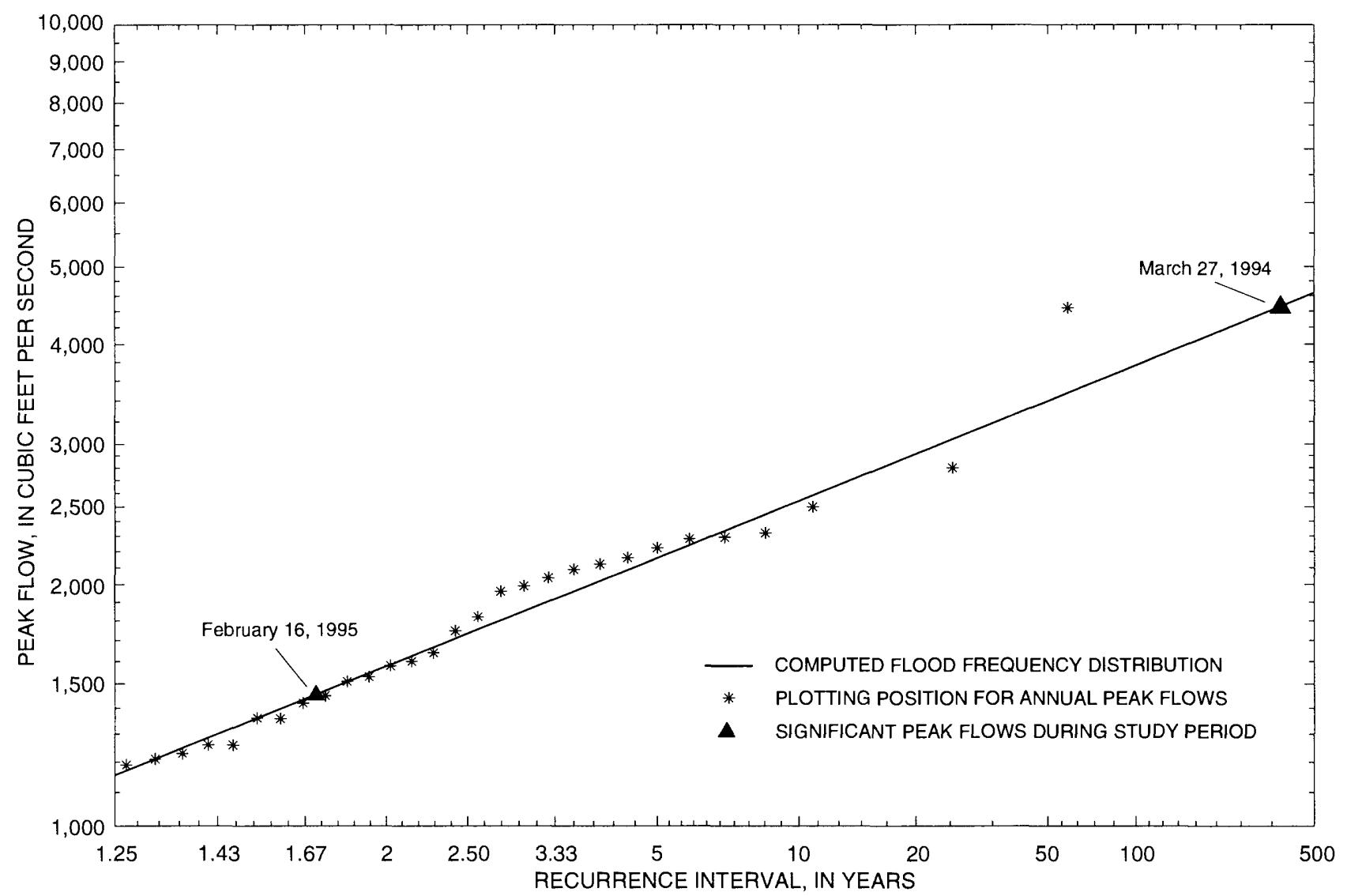

Figure 2. Computed flood-frequency distribution for Scott Creek above Sylva, N.C. 
formerly of the Jackson County Planning Department, is gratefully acknowledged. In addition, the advice and assistance of Mr. Chris Hughes and Mr. Roger A. Milstead, Tennessee Valley Authority, in providing the data used in computing the water-surface profiles and in applying the HEC-2 to those data are gratefully acknowledged.

\section{PEAK FLOW SIMULATION}

Peak flows were simulated at site 1 (fig. 1; table 1) using a calibrated version of the RRM to represent the response of the basin to selected hypothetical 24-hour rainfall events under high-, moderate-, and low-antecedent moisture conditions. This section describes the RRM and the calibration of the model for the Scott Creek Basin. Synthesis of the data set used in simulating the hypothetical events and applying the data set to the calibrated model are described. Results of the simulations are then presented.

\section{Rainfall-Runoff Model Description and Calibration}

The RRM, originally developed and documented by Dawdy and others (1972), simulates flow volumes and flow rates of surface runoff from small drainage basins. Its use is generally restricted to small basins so as not to violate the basic model assumptions:

(1) ground-water contribution to the hydrograph is neglible, (2) rainfall is uniform across the basin and can be adequately represented by a single rainfall input, and (3) pertinent physical characteristics of the basin can be represented by basin-average values. The model has three primary components-soil-moisture accounting; excess rainfall, or surface-runoff, computation; and surface-runoff routing. Eleven model parameters are used to simulate volume and flow rate of surface runoff generated by rainfall events. Several modifications have been made to the original model, most notably the inclusion of an automated routine for optimization of model parameters during model calibration based on comparison of simulated flow volumes and flow rates to observed values (E.J. Inman, U.S. Geological Survey, written commun., May 1994).

The RRM operates in two modes - a daily mode and a storm mode. In the daily mode, daily rainfall and evaporation values are used to simulate the distribution of soil moisture in the soil column and evapotranspira- tion from the soil. In the storm mode, short-interval (15 minutes for the Scott Creek Basin) rainfall data and output from the daily soil-moisture accounting are used to determine the amount of excess rainfall, or runoff volume, that results from each storm event. The runoff volume is then routed through the channel to create a flow hydrograph, which provides the time distribution of flows, including the peak flow, at the basin outlet. A more detailed description of the model algorithms is provided by Dawdy and others (1972).

Site 1 (fig. 1) has a drainage area of $51.0 \mathrm{mi}^{2}$, which is somewhat large for the application of the RRM. However, basin characteristics and results of model calibration suggest that the RRM can be successfully applied to the Scott Creek Basin.

Although the Scott Creek Basin is fairly large, land use and terrain are fairly uniform throughout, except for some small areas near the main stream. Because of this uniformity, it is reasonable to assume that average basinwide values can adequately describe the physical characteristics of the basin. Large groundwater contributions to the storm hydrograph usually occur in basins with thick, very transmissive layers of underlying soils. Because of the mountainous location of the Scott Creek Basin and the relatively shallow soils that are typical of such locations, the assumption of no significant ground-water contribution to the storm hydrograph can be made.

The assumption required for the application of the RRM that rainfall is uniform over the Scott Creek Basin is likely violated on occasion. Without a more dense network of raingages, however, it is difficult to determine true basinwide distribution of rainfall. A practical test of the assumption of uniform rainfall in the basin is the ability to adequately calibrate the model for a range of observed rainfall amounts and the resulting flows.

Model calibration is the process of adjusting model parameters such that simulated runoff volumes and flow rates agree with the corresponding observed runoff volumes and flow rates. For this investigation, calibration of the model was achieved using an automated parameter-optimization routine. This routine performs a systematic trial and error search for a set of model parameters that minimize selected combinations of five objective functions. Three of the objective functions measure error between simulated and observed values of runoff volume and peak flow for each rainfall-runoff event; the remaining two objective functions involve a combination of error and the slope 
of a regression line of simulated with observed values. Calibration procedures used in this study follow closely those described by Robbins and Pope (1996) in a study involving calibration of RRM for a number of small urban basins in North Carolina.

The quality of calibration is measured by the standard error of regression between simulated and observed values of respective runoff volume and peak flow, by the slopes of these regression lines, and by inspection of plots of simulated and observed values. A slope of 1.0 usually indicates no bias in the calibration, or that the tendency to over- or undersimulate observed values is not a function of the magnitude of the values. Inspection of the plots of simulated and observed values is used to confirm lack of bias.

Fourteen high-flow events from the discharge record at site 1 for the period March 1994 through September 1995 were selected for use in model calibration. Peak flows at site 1 (fig. 1 ; table 1) for these events were between 196 and 4,440 ft 3 , and total storm rainfall measured at site 2 (fig. 1 ; table 1 ) for these events ranged from 0.48 to 6.25 in. (table 2). Recorder malfunctions resulted in missing rainfall record for 2 of the 14 events at site 3 (fig. 1; table 1) and 5 of the 14 events at site 4 (fig. 1; table 1). Average absolute values of the percent differences between total storm rainfall measured at site 2 and total storm rainfall measured at sites 3 and 4 were 40 and 21 percent, respectively.

Separate RRM calibrations were performed for the selected high-flow events using rainfall data from each of the three rainfall gages within the basin (fig. 1; table 1). Calibrations using unit rainfall data from sites 3 and 4 resulted in regression line slopes for volumes that statistically differed from 1.0 and large standard errors (greater than 58 percent for peaks and greater than 43 percent for volumes). However, for the calibration using rainfall data from site 2 , the slopes of the regression lines for both runoff volumes and peak flows were not statistically different from 1.0 , and inspection revealed no bias (fig. 3). In addition, using rainfall data from site 2 , standard errors of regression for runoff volumes and peak flows were 34 percent and 21 percent, respectively. These standard errors of regression are of similar magnitude to those achieved

Table 2. Total storm rainfall, observed and simulated runoff volumes, and observed and simulated peak flows for events used in calibration of the RRM

\begin{tabular}{ccccc}
\hline $\begin{array}{c}\text { Total storm rainfall } \\
\text { at site 2 } \\
\text { (inches) }\end{array}$ & $\begin{array}{c}\text { Observed volume } \\
\text { (inches) }\end{array}$ & $\begin{array}{c}\text { Simulated volume } \\
\text { (inches) }\end{array}$ & $\begin{array}{c}\text { Observed peak } \\
\text { flows at site 1 } \\
\text { (ft } \mathbf{3}^{\text {/s) }} \text { ) }\end{array}$ & $\begin{array}{c}\text { Simulated peak } \\
\text { flows at site 1 } \\
\text { (ft }^{3} / \mathbf{s} \text { ) }\end{array}$ \\
\hline 0.47 & 0.02 & 0.02 & 196 & 169 \\
.55 & .04 & .05 & 274 & 307 \\
.63 & .04 & .03 & 281 & 257 \\
.64 & .05 & .05 & 256 & 256 \\
.73 & .05 & .05 & 236 & 230 \\
1.06 & .09 & .08 & 256 & 258 \\
1.13 & .21 & .08 & 339 & 282 \\
1.21 & .21 & .25 & 744 & 915 \\
1.26 & .09 & .16 & 413 & 546 \\
1.40 & .27 & .23 & 935 & 1,001 \\
1.74 & .33 & .35 & 1,138 & 1,127 \\
2.84 & .48 & .44 & 881 & 962 \\
4.03 & 1.14 & .96 & 1,406 & 1829 \\
6.25 & 2.37 & 2.49 & 4,204 & 4,403 \\
\hline
\end{tabular}



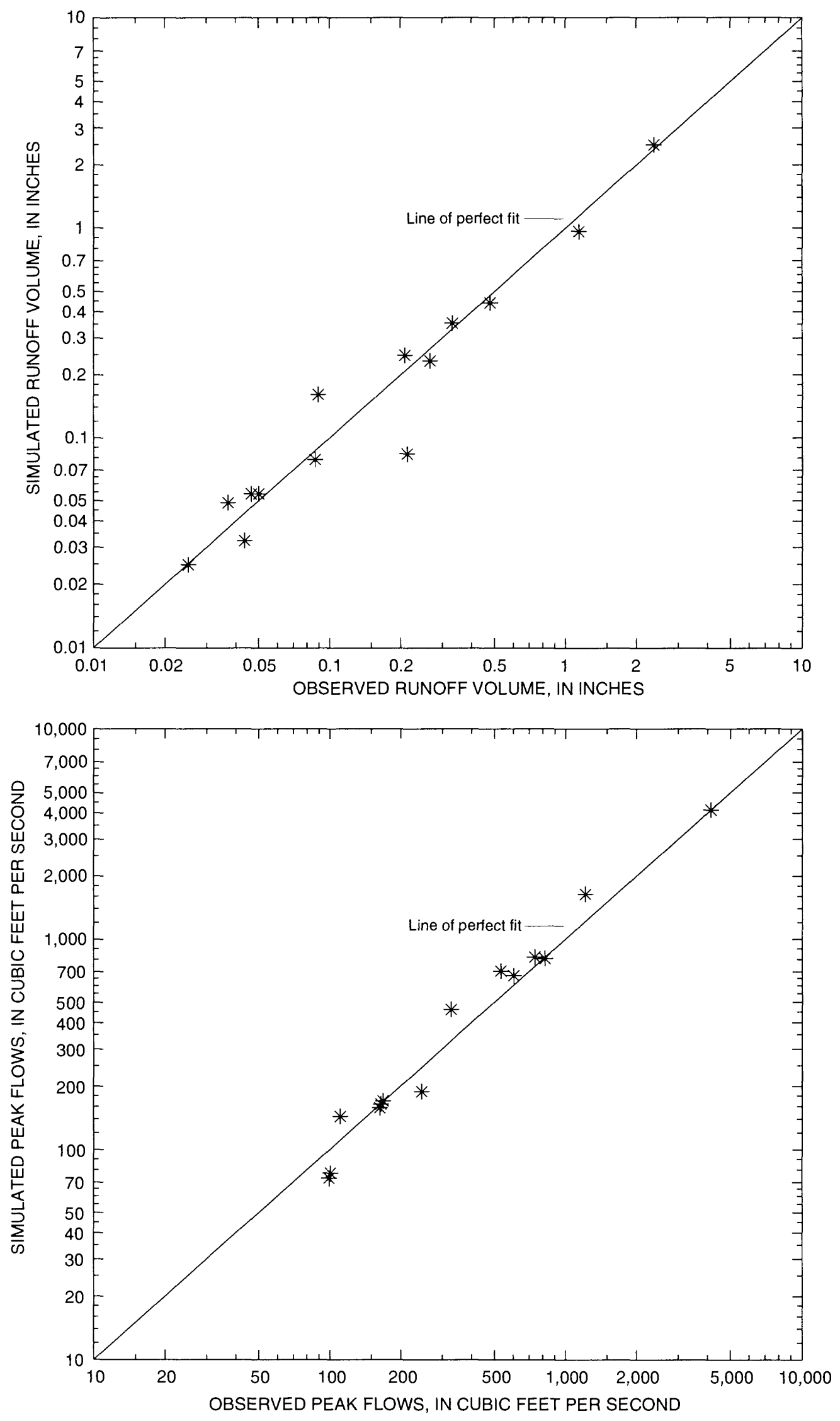

Figure 3. Simulated and observed runoff volumes and peak flows for Scott Creek above Sylva, N.C. 
by Robbins and Pope (1996) for other basins in North Carolina.

The RRM was calibrated for simulating peak flows at site 1 using streamflow recorded at site 1 , rainfall measured at site 2 , and evaporation measured at site 6 (fig. 1 ; table 1 ). Site 2 is near the center of the basin and probably more closely approximates basinwide rainfall than the other two rainfall gages. The standard errors of regression, along with a lack of bias, indicate that the RRM adequately simulates the Scott Creek Basin response to the range of rainfall amounts measured at site 2 and used in the calibration.

\section{Antecedent Conditions and Synthetic Rainfall Data}

The RRM requires daily rainfall and evaporation data for the period preceding a storm event in order to simulate the antecedent soil-moisture conditions. Soilmoisture conditions control the amount of infiltration and subsequently the volume of runoff during an event. Consequently, peak flow for a given rainfall will vary with antecedent moisture conditions. Hence, it is reasonable to simulate the response of the Scott Creek Basin to rainfall for a range of antecedent conditions.

Concurrent daily records of rainfall from the NWS Asheville weather station and evaporation from the USFS Coweeta Experimental Station from 1949 to 1989 were used to analyze moisture conditions. Daily evaporation was subtracted from daily rainfall; this difference was defined as the daily moisture. Monthly moistures are defined as the sum of the daily moisture amounts for each month. The values were grouped into climatic years (April through March), and the mean monthly moistures from 1949 to 1989 were computed and plotted. By examination, mean monthly moistures were grouped into 3-month periods representing low-, moderate-, and high-moisture conditions. May through July represents the low-moisture period, August through October represents the moderate-moisture period, and December through February represents the high-moisture period (fig. 4).

The individual monthly moistures for each 3-month period were summed for each climatic year of

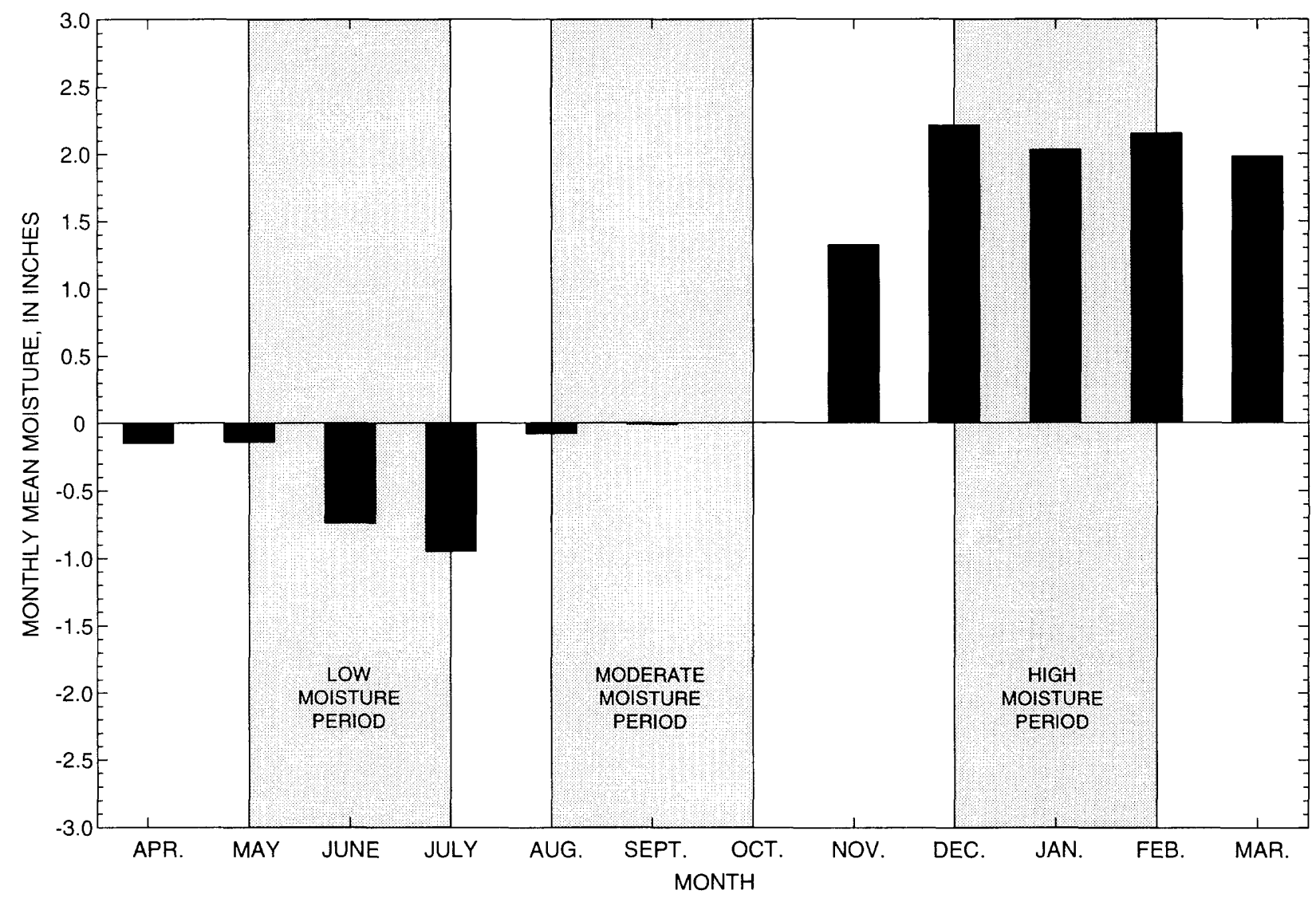

Figure 4. Monthly means of total moisture for climatic years 1949-89. 
record, giving three annual series of moistures. The values in each series were ranked in ascending order, and the 10th, 50th, and 90th percentiles of moisture were computed for each series. The observed 3-month sums that most closely matched the 90th percentile of the wet period, the 50th percentile of the moderate period, and the 10th percentile of the dry period were selected for use in the simulations (table 3 ). The original daily rainfall and evaporation records for the selected periods were used as input to the RRM.

Table 3. Period and total rainfall for antecedent moisture conditions data used in peak-flow simulations

\begin{tabular}{lccc}
\hline $\begin{array}{c}\text { Antecedent } \\
\text { moisture } \\
\text { condition }\end{array}$ & Period used & $\begin{array}{c}\text { Total } \\
\text { moisture } \\
\text { (inches) }\end{array}$ & $\begin{array}{c}\text { Total } \\
\text { rainfall } \\
\text { (inches) }\end{array}$ \\
\hline High & $\begin{array}{c}\text { December 1986 - } \\
\text { February 1987 }\end{array}$ & 10.44 & 10.44 \\
Moderate & August - October 1950 & -1.12 & 6.73 \\
Low & May 1977 - July 1977 & -5.56 & 6.35 \\
\hline
\end{tabular}

During the high-moisture period, total moisture was a function of rainfall alone; no evaporation was recorded, and total rainfall was the same as total moisture. For the moderate- and low-moisture periods, however, evaporation governed moisture condition; rainfall amounts were nearly equal for the two periods, but total moistures differed by 4.44 in. The difference in moisture between high- and moderate-moisture periods is 11.56 in., about 2.5 times the difference between moderate- and low-moisture periods (table 3 ).

The range of rainfall events for which flows would be simulated were the selected 24 -hour rainfall amounts of 1.0, 2.5, 5.0, and 7.5 in. These amounts are approximately $20,50,100$, and 150 percent of the 24-hour rainfall of 5.13 in. that resulted in the peak flow of 4,440 ft $3 / \mathrm{s}$ that occurred on March 27, 1994 (fig. 2). This flow is the maximum recorded in 37 years of record and has an estimated recurrence interval of greater than 200 years. Therefore, it is reasonable to use the rainfall that resulted in this peak flow as the basis for developing a range of synthetic unit rainfall inputs.

Several possible time distributions of these total rainfall amounts were considered for use in simulating peak flows. A reasonable set of distributions were developed by Huff (1967) and are based on analysis of rainfall data collected from about 50 rainfall gages in Illinois from 1955 to 1966. A time distribution of total storm rainfall that approximates the 50-percent probability distribution of second-quartile storms, as described by Huff (1967), was used to develop the synthetic unit rainfall distributions for this study. A second-quartile storm is one in which the heaviest rainfall occurs during the second quarter of the total storm period; the 50-percent probability distribution is the distribution that has a 50-percent chance of occurring. The time distribution of discharge is likely dependent on the time distributions of rainfall; however, in this study, only the second quartile distribution, the most frequently occurring storm type, was used (Huff, 1967).

\section{Simulation Results}

Peak flows were simulated by using selected daily rainfall and evaporation data, and synthetic storm rainfall distributions with the calibrated model. Three peak flows were simulated for each 24-hour rainfall amount, one each for the three sets of paired daily rainfall and evaporation data representing low-, moderate-, and high-antecedent moisture conditions (table 4).

Table 4. Simulated peak flows for selected 24-hour rainfall amounts and antecedent moisture conditions [ $\mathrm{ft}^{3} / \mathrm{s}$, cubic feet per second]

\begin{tabular}{cccc}
\hline & \multicolumn{3}{c}{ Simulated peak flow } \\
\cline { 2 - 4 } $\begin{array}{c}\text { 24-hour } \\
\text { rainfall } \\
\text { (inches) }\end{array}$ & $\begin{array}{c}\text { Low- } \\
\text { antecedent } \\
\text { moisture } \\
\left(\mathrm{ft}^{3} / \mathbf{s}\right)\end{array}$ & $\begin{array}{c}\text { Moderate- } \\
\text { antecedent } \\
\text { moisture } \\
\left(\mathrm{ft}^{3} / \mathbf{s}\right)\end{array}$ & $\begin{array}{c}\text { High- } \\
\text { antecedent } \\
\text { moisture } \\
\left(\mathrm{ft}^{3} / \mathbf{s}\right)\end{array}$ \\
\hline 1.0 & 89.2 & 102 & 213 \\
2.5 & 674 & 814 & 1,740 \\
5.0 & 3,550 & 4,070 & 5,860 \\
7.5 & 7,660 & 8,240 & 10,100 \\
\hline
\end{tabular}

As expected, the range of 24-hour rainfall amounts resulted in a wide range of simulated peak flows-from 89 to $10,100 \mathrm{ft}^{3} / \mathrm{s}$. The difference in flow because of antecedent moisture conditions is greater between moderate- and high-moisture conditions than between low- and moderate-moisture conditions (fig. 5). This is likely because of the relative differences in total moisture amounts among the three periods (table 3). 


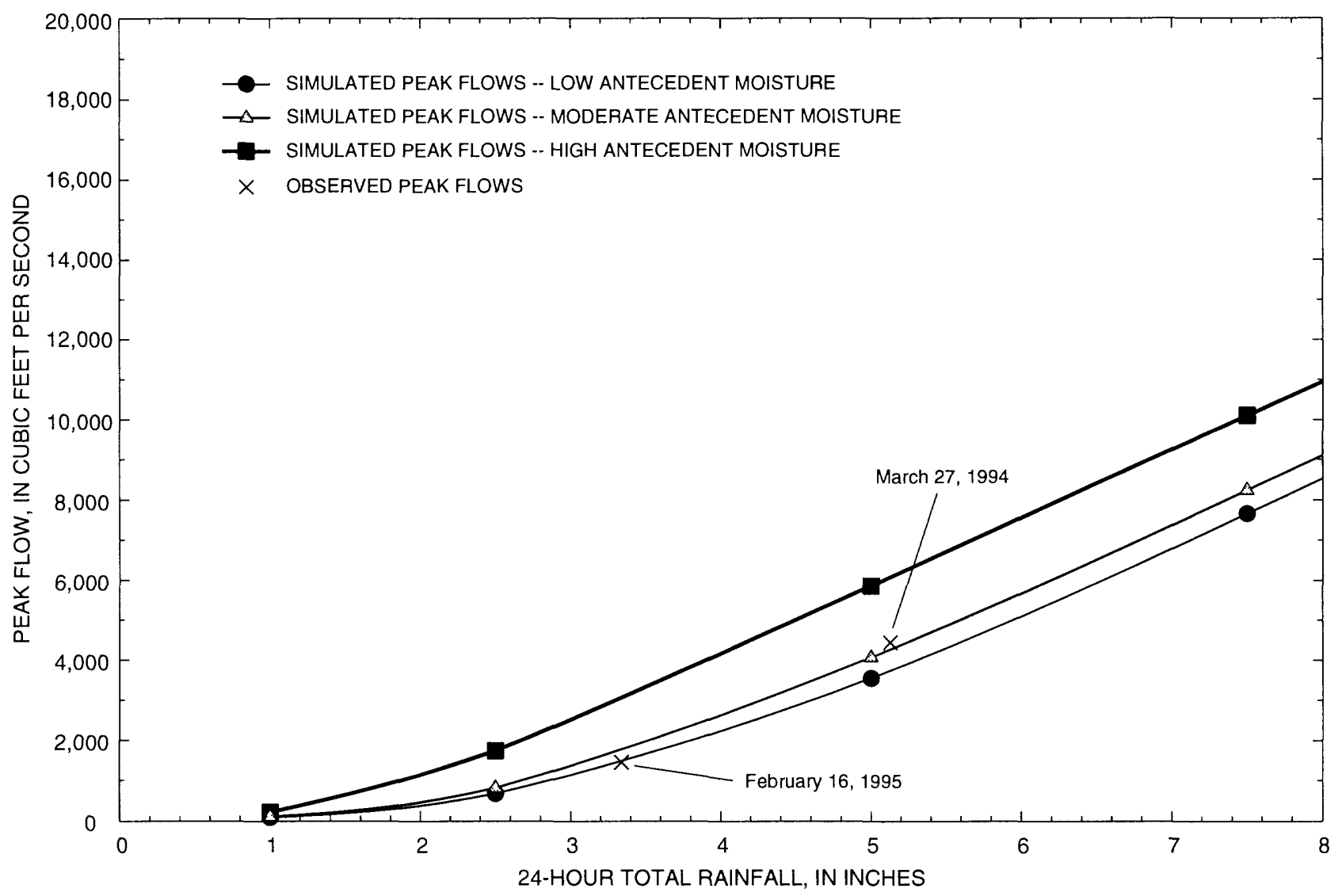

Figure 5. Simulated and observed peak flows for Scott Creek above Sylva, N.C., in response to selected 24-hour rainfall events.

The RRM produces a simulated flood hydrograph for each storm event. Because each hydrograph is simulated using the same time to peak and recession slope developed in model calibration, hydrographs for the 18 simulated storms have only minor differences in shape. These hydrographs were normalized by dividing flow $(Q)$ by the peak flow $(Q p)$ and time $(T)$ by the time to peak $(T p)$ and the minor differences averaged. In a similar fashion, plots of rainfall intensity were normalized by dividing intensity ( $I$ ) by peak intensity (IP) and plotted against the normalized time of the hydrograph (fig. 6).

For this synthetic rainfall distribution, the peak simulated flow occurs before the end of rainfall, at about two-thirds of the total storm duration. The implication of this timing is that about 90 percent of the 24-hour rainfall contributes to the peak flow, and the remainder contributes to flow after the peak. Therefore, for this rainfall distribution, there is only a short period of time between the occurrence of peak rainfall intensity and the occurrence of peak flow. For example, for a 24-hour storm the peak flow occurs about 15 hours after rainfall begins and about 6 hours after peak rainfall intensity for this synthetic rainfall distribution. Other rainfall distributions would result in different relations between time of maximum rainfall intensity and occurrence of peak flow.

\section{WATER-SURFACE PROFILES}

The peak flows simulated and presented in this report are for site 1 only (fig. 1). In general, peak flow increases with distance downstream and decreases with distance upstream. In addition, a peak flow is of little use in determining the extent of flooding without a means of associating the flow with a water-surface elevation. For these reasons, it is desirable to transfer flows at a single point to points upstream and downstream and compute a profile of water-surface elevations along the stream reach for selected flows of interest. This approach has been applied to Scott Creek 

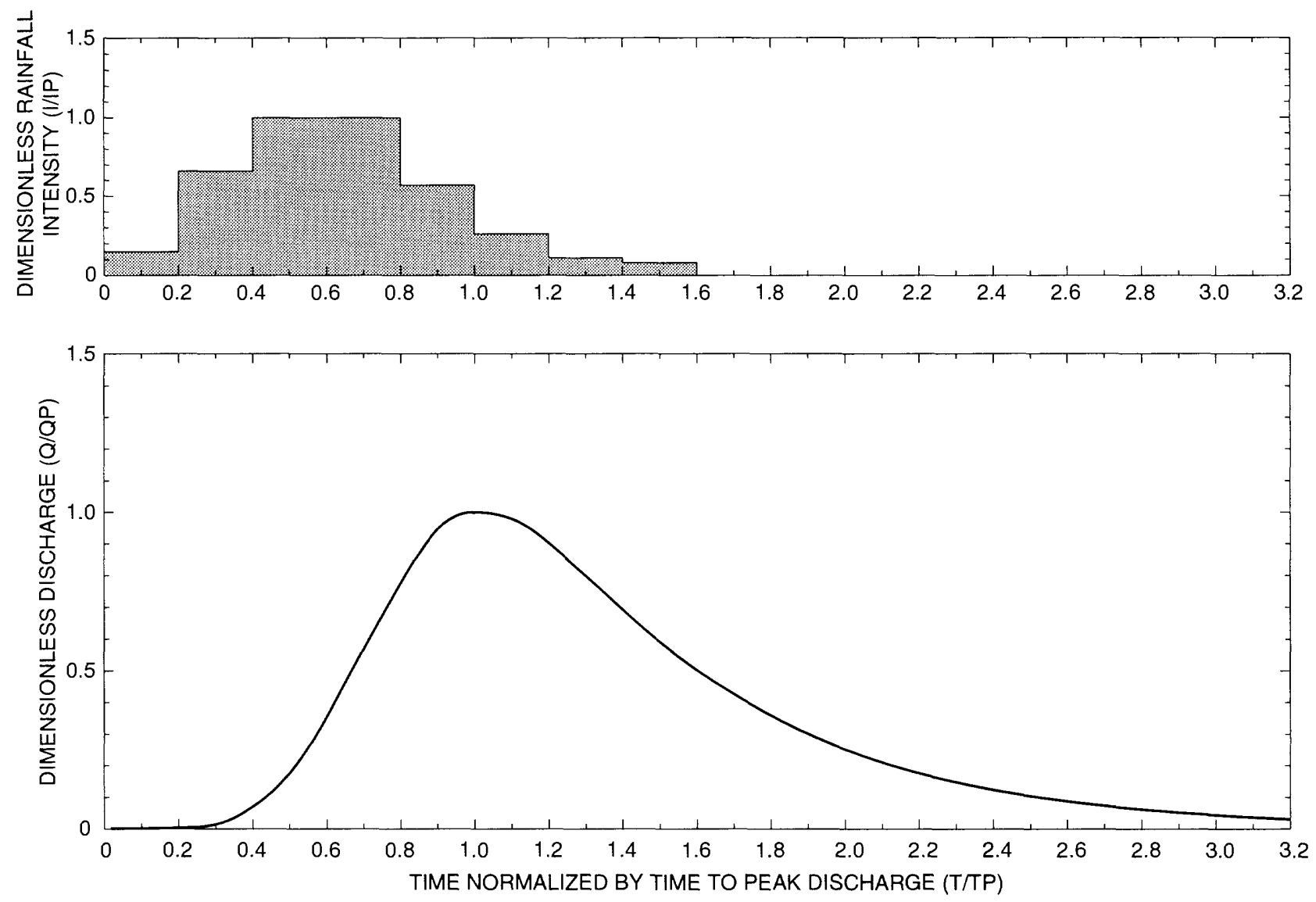

Figure 6. Dimensionless input rainfall intensity and average dimensionless simulated flood hydrograph for Scott Creek above Sylva, N.C.

in studies by the Federal Emergency Management Agency (FEMA), in which water-surface profiles for flows of selected recurrence intervals were developed and presented (Federal Emergency Management Agency, 1989, 1990).

Computation of the profiles for the FEMA studies was done by TVA personnel using the U.S. Army Corps of Engineers HEC-2 Water Surface Profiles computer program (R.A. Milstead, Tennessee Valley Authority, oral commun., July 1996). Elevations, geometries, and hydraulic properties of cross sections located along the stream reach of interest are needed for the HEC-2 to compute a water-surface profile for specified flows. A detailed survey of cross sections and field determination of the hydraulic properties of the cross sections are required to develop the data necessary to apply HEC-2. The elevation, geometry, and hydraulic property data used by the TVA in their analyses (R.A. Milstead, Tennessee Valley
Authority, written commun., June 28, 1996) were obtained and used to compute water-surface profiles for flows simulated in this study.

In order to use HEC-2, the simulated flows at site 1 (fig. 1; table 1) were transferred upstream to the beginning of the reach, at a drainage area of $49.1 \mathrm{mi}^{2}$, and downstream to the end of the reach, at a drainage area of $59.0 \mathrm{mi}^{2}$, using a drainage-area ratio. Flows for cross sections along the reach were determined by a linear interpolation of drainage area.

Water-surface profiles were determined using HEC-2 for the observed peak flow of $4,440 \mathrm{ft}^{3} / \mathrm{s}$ and for the simulated peak flow of $8,240 \mathrm{ft}^{3} / \mathrm{s}$ (table 4) from a point $1,500 \mathrm{ft}$ upstream from the mouth of Scott Creek to a point 22,500 ft upstream from the mouth (fig. 7). Profiles for intermediate peak flows were not presented because they were so close in elevation that they were indistinguishable at the scale used. Water-surface profiles for higher peak 


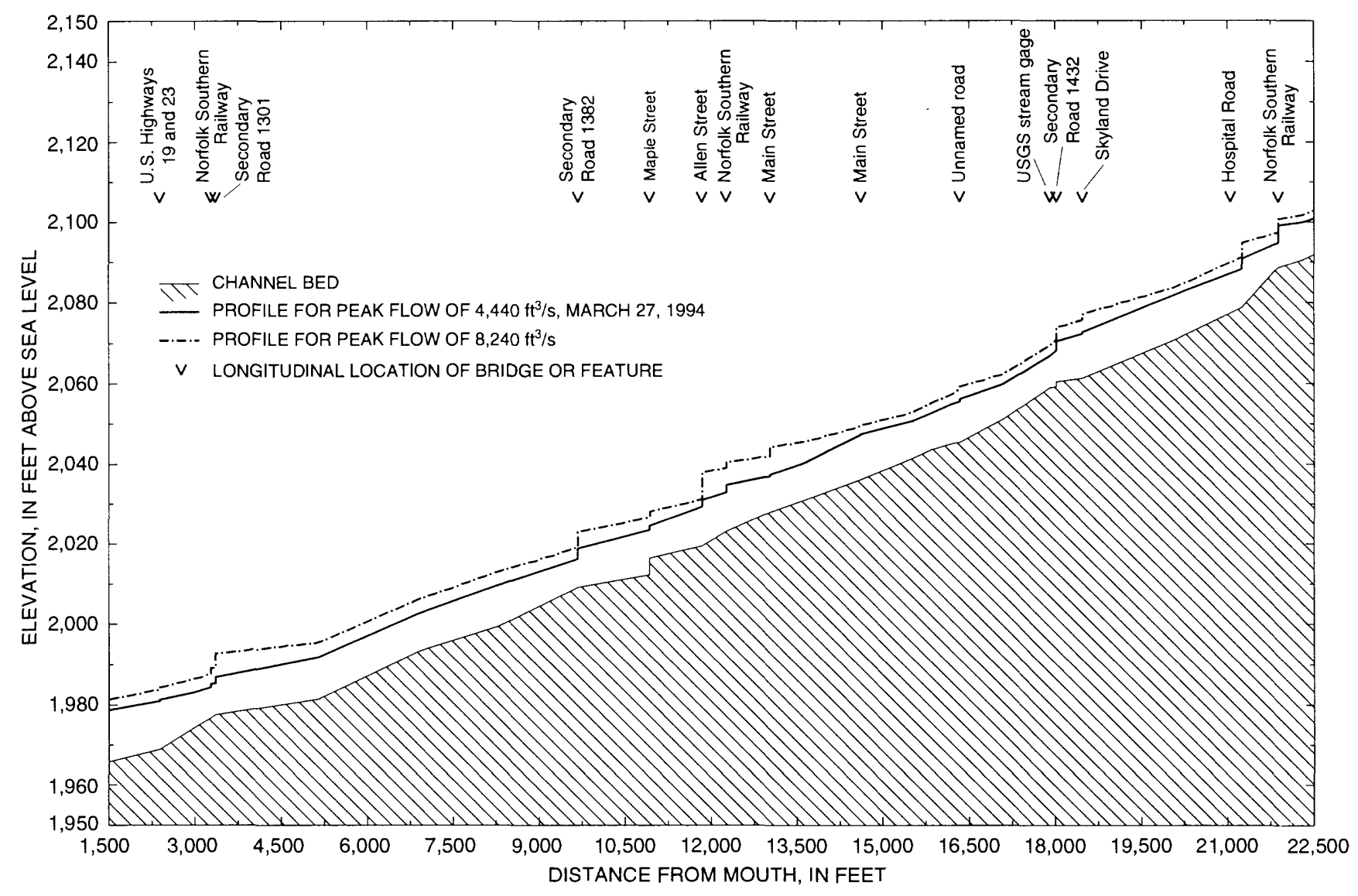

Figure 7. Water-surface profiles for selected observed and simulated peak flows along the reach of Scott Creek flowing through Sylva, N.C.

flows were not determined because of the very low probability of occurrence of such flows.

The water-surface profiles presented are representative of the conditions described by the cross section and hydraulic property data provided by the TVA, which were gathered during the execution of the FEMA study during 1988-89. A comparison of stagedischarge relations, or rating curves, for Scott Creek above Sylva from the earlier period of record (1942-75) and the study period (1993-95) indicates a considerable change in the hydraulic properties of the stream at the simulation site (fig. 8).

The relative change in the rating curves, however, is such that the stage associated with a given flow has decreased with time (fig. 8). A comparison of the observed peak stage for the $4,440 \mathrm{ft}^{3} / \mathrm{s}$ flow, about $2,063 \mathrm{ft}$ above sea level, with the elevation taken from the computed profile at the gage location (site 1), which is about 2,067 ft above sea level, further illustrates this change. Therefore, water-surface profiles presented in this report likely overestimate the true water-surface elevation for a given flow at site 1 .

\section{APPLICATION OF RESULTS}

The simulated peak flows and associated watersurface profiles presented in this report represent the response of the Scott Creek Basin to several hypothetical combinations of synthesized antecedent moisture conditions and 24-hour rainfall amounts. Because these hypothetical conditions will likely not be exactly reproduced by natural events, the peak flows and elevations presented are intended to be used as a qualitative guide to the response of the basin to actual conditions. Errors in the rainfall-runoff model, differences between the hypothesized and actual antecedent moisture conditions, and differences in the distribution of rainfall between the synthesized and 


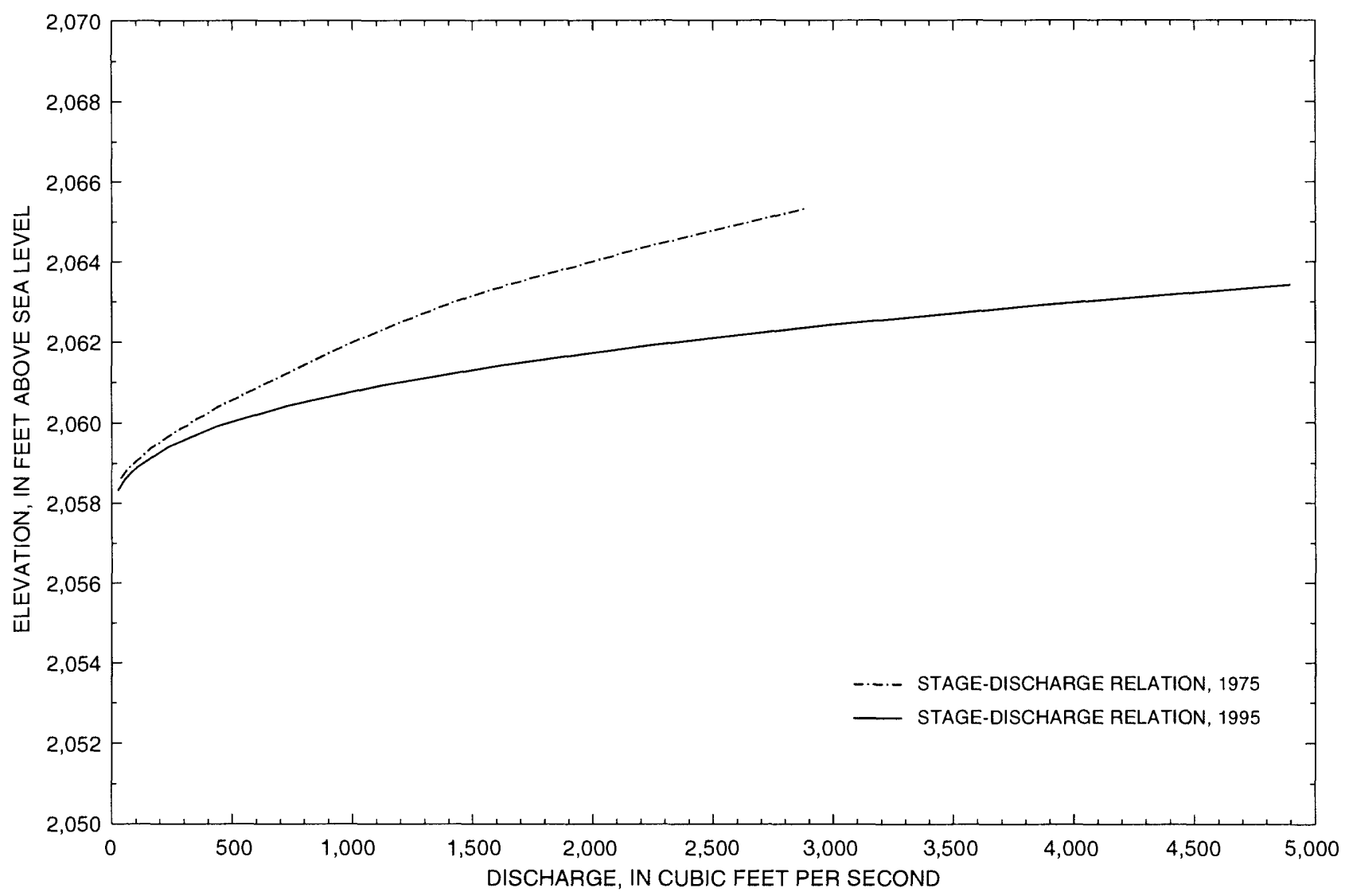

Figure 8. Stage-discharge relations (rating curves) in effect in 1975 and 1995 for Scott Creek above Sylva, N.C.

actual storm events should be considered when using the results of this report.

As an example, consider a predicted 24-hour rainfall amount. Antecedent moisture conditions can be estimated by referring to published climatic records for the previous 3 months. Then, given the predicted rainfall total and estimated antecedent moisture conditions, the simulated peak flow for those conditions can be determined (fig. 6; table 4). This peak flow can then be compared to the peak flows associated for which computed water-surface profiles are presented (fig. 7), and an estimate of the potential water-surface elevation resulting from the predicted 24-hour rainfall amount can be determined. Estimated peak flow and water-surface elevations resulting from such an analysis provide an approximation of the relative magnitude of the response of the Scott Creek Basin to actual 24-hour rainfall amount and antecedent moisture conditions.

\section{SUMMARY}

Peak flows were simulated for Scott Creek in Jackson County, North Carolina, using a calibrated version of the USGS rainfall-runoff model. Peak flows ranging from 89 to $10,100 \mathrm{ft}^{3} / \mathrm{s}$ were simulated in response to synthetic unit rainfall distributions for 24-hour storm rainfall amounts ranging from 1.0 to 7.5 in. Each peak flow was simulated under low-, moderate-, and high-antecedent moisture conditions, represented by 3 -month periods of daily rainfall and evaporation. These periods were selected on the basis of an analysis of 37 years of records from two nearby climatic stations.

The model was calibrated using observed flow and rainfall data for 14 storms collected from March 1994 to September 1995. During the data-collection period, a peak flow of $4,440 \mathrm{ft}^{3} / \mathrm{s}$ was observed on March 27, 1994. This flow has a recurrence interval greater than 200 years and is the maximum observed 
flow for the periods of record at the gage, 1942-75 and 1993-95.

Water-surface profiles were computed along the reach of Scott Creek flowing through Sylva, N.C., for selected simulated and observed flows. The watersurface profiles were computed using data obtained from the TVA and according to procedures generally equivalent to those used in previous FEMA studies of Scott Creek. As a result of changes in the stagedischarge relation at the simulation site since the data were collected by TVA, the profiles determined for this investigation likely overestimate true water-surface elevations for a given flow at the simulation site.

\section{REFERENCES}

Barker, R.G., George, E.D., Rinehardt, J.F., and Eddins, W.H., 1994, Water resources data, North Carolina, water year 1993: U.S. Geological Survey Water-Data Report NC-93-1, $580 \mathrm{p}$.

Dawdy, D.R., Lichty, R.W., and Bergmann, J.M., 1972, A rainfall-runoff simulation model for estimation of flood peaks for small drainage basins: U.S. Geological Survey Professional Paper 506-B, 28 p.
Federal Emergency Management Agency, 1989, Flood insurance study, Jackson County, North Carolina, unincorporated areas: $15 \mathrm{p}$. revised 1990, Flood insurance study, Town of Sylva, North Carolina, Jackson County: 6 p.

Huff, F.A., 1967, Time distribution of rainfall in heavy storms: American Geophysical Union, Water Resources Research, v. 3, no. 4, p. 1007-1019.

Ragland, B.C., Smith, D.G., Barker, R.G., and Rinehardt, J.F., 1995, Water resources data, North Carolina, water year 1994: U.S. Geological Survey Water-Data Report NC-94-1, 578 p.

1996, Water resources data, North Carolina, water year 1995: U.S. Geological Water-Data Report NC95-1, $618 \mathrm{p}$.

Robbins, J.C., and Pope, B.F., 1996, Estimation of floodfrequency characteristics of small urban streams in North Carolina, 1995: U.S. Geological Survey WaterResources Investigation Report 96-4084, 21 p.

U.S. Army Corps of Engineers Hydrologic Engineering Center, 1991, HEC-2 Water surface profiles user's manual: U.S. Army Corps of Engineers CPD-2A, $308 \mathrm{p}$.

U.S. Water Resources Council, 1981, Guidelines for determining flood flow frequency: U.S. Water Resources Council Bulletin 17B, 183 p. 


\section{APPENDIX}

Table A-1. Units, definition, and calibrated value for the RRM parameters used in peak flow simulation at Scott Creek above Sylva, N.C.

[-, not applicable]

\begin{tabular}{|c|c|c|c|}
\hline Parameter & Units & Definition & Calibrated value \\
\hline \multicolumn{4}{|c|}{ Antecedent soil-moisture accounting component } \\
\hline EVC & - & $\begin{array}{l}\text { Coefficient to convert pan evaporation to potential } \\
\text { evapotranspiration }\end{array}$ & 0.750 \\
\hline RR & - & Proportion of daily rainfall that infiltrates the soil & .500 \\
\hline BMSM & inches & Soil moisture storage volume at field capacity & 14.36 \\
\hline DRN & $\begin{array}{l}\text { inches per } \\
\text { hour }\end{array}$ & $\begin{array}{l}\text { The constant rate of drainage for redistribution of } \\
\text { soil moisture }\end{array}$ & 1.00 \\
\hline \multicolumn{4}{|c|}{ Infiltration component } \\
\hline PSP & inches & $\begin{array}{l}\text { Minimum value of the combined action of } \\
\text { capillary suction and soil moisture differential }\end{array}$ & 0.505 \\
\hline KSAT & $\begin{array}{l}\text { inches per } \\
\text { hour }\end{array}$ & $\begin{array}{l}\text { Minimum saturated hydraulic conductivity used } \\
\text { to determine soil infiltration rates }\end{array}$ & .021 \\
\hline RGF & - & $\begin{array}{l}\text { Ratio of combined action of suction and potential } \\
\text { at wilting point to that at field capacity }\end{array}$ & 20.76 \\
\hline EIA & - & $\begin{array}{l}\text { Effective ratio of impervious area to total basin } \\
\text { area; a measure of the impervious area that is } \\
\text { directly connected to the channel drainage } \\
\text { system }\end{array}$ & .029 \\
\hline \multicolumn{4}{|c|}{ Surface-runoff routing component } \\
\hline KSW & hours & Linear reservoir routing coefficient & 8.45 \\
\hline $\mathrm{TC}$ & minutes & $\begin{array}{l}\text { Duration of the triangular translation hydrograph } \\
\text { (time of concentration) }\end{array}$ & 235.8 \\
\hline TP/TC & - & Ratio of time to peak to time of concentration & .500 \\
\hline
\end{tabular}

